\title{
Correction to: An evaluation of the in vitro antioxidant and antidiabetic potentials of camel and donkey milk peptides released from casein and whey proteins
}

\author{
Ecem Akan ${ }^{1}$ (D)
}

Published online: 25 March 2021

(C) Association of Food Scientists \& Technologists (India) 2021

\section{Correction to: J Food Sci Technol} https://doi.org/10.1007/s13197-020-04832-5

In the original version of the article, the author would like to add a line to the acknowledgements section. The revised acknowledgements is given below.
I would like to thank Prof. Dr. Ali Adnan Hayaloglu for HPLC analysis.

The original article can be found online at https:// doi.org/10.1007/s13197-020-04832-5.

Ecem Akan

ecem.akan@adu.edu.tr

1 Faculty of Agriculture, Department of Dairy Technology, Aydın Adnan Menderes University, 09970, Koçarlı, Aydın, Turkey 